\section{EAR, NOSE AND THROAT DISEASES FOR THE GENERAL PRACTITIONER}

By William McKenzie, M.B., B.Chir., F.R.C.S. Pp. vii + 136, with I I illustrations. Edinburgh: E. \& S. Livingstone. 1952. 95 .

This is a small readable book with no complicated diagrams or unnecessary details. It stresses the importance of history and general examination and the necessity of regular toilet by a trained person for aural discharge, whether it be due to otitis media or externa.

There is some doubt as to the need for audiograms in a book of this type and as to their appreciation by the general practitioner. As regards fenestration, there is too much about the operation and too little about the type of patient suitable for it. The author stresses that nasal infection is often responsible for an aural condition and that the autra are by no means above suspicion as the source. Other important points are that hoarseness persisting for more than a month must be properly investigated, and that a general anaesthetic is essential in dealing with foreign bodies in juvenile ears and noses.

Finally, he issues a warning about the dangers and futility of local treatment with penicillin and sulphonamides in E.N.T. conditions.

This is not a pretentious book. In what it covers it is both clear and sound. It is recommended.

C.M.W.

\section{THE BRITISH ENCYCLOPAEDIA OF MEDICAL PRACTICE \\ Vols. 7 and 8}

Edited by The RT. Hon. LoRD HoRder, G.C.V.O., M.D., F.R.C.P. 2nd Edition. Vol. 7, Pp. xv + 707, with 188 illustrations. Vol. 8, Pp. xvi + 670, with 48 illustrations, 2 in colour. London: Butterworth \& Co. 1951. $£ 3$ each volume.

Of the 90 chapters which comprise these two volumes, nearly 50 have been written or revised by new authors, and seven new chapters have been included in volume 8 .

The rapid development of new surgical and anaesthetic techniques in the past decade has led to the introduction of a valuable new and comprehensive chapter on local and regional anaesthesia by Dr. Massey Dawkins. The old chapter on seasickness has given way to a more expansive account on motion sickness, based on new knowledge of the anti-histamine drugs and the experience of World
War II. Dr. Tegner has given new meaning to the layman's term 'lumbago in a useful paper whicb should do much to give respectability to this diagnosis-even amongst doctors. A much needed chapter on life assurance by Dr. T. W. Preston wit be generally welcomed. Clarification of the aetiologo of melaena neonatorum and its identity with vitamis. $\mathrm{K}$ deficiency has given us a new section by Drin A. P. M. Page.

Amongst the many authors whose names appear for the first time in the present volumes, it is 2 pleasure to welcome some of the younger cons tributors. Dr. W. H. Tattersall, particularly@ should be mentioned for his excellent account of pulmonary tuberculosis. This section has been entirely recast and brought up to date. It is a pityg however, that the author should detract from hispaper by incorrect emphasis and relegating the prevention of tuberculosis to the tail-end of ght chapter. Dr. S. Oram has collaborated in writing a new section on lung embolus. What there is of this necessary addition is good, but the importan problems of fat embolism, chronic pulmonary embolism and embolic obstruction of the lungs bot tumour cells (which is not rare) are completel ignored.

The production of these two volumes is, of course excellent, but it is felt that more use might have been made of half-tone pictures and coloured plates which have been such pleasing and helpful features. of most of the earlier volumes.

\section{FOOD AND NUTRITION}

D.S.L.

By E. W. H. Cruickshank, M.D., D.Sc., Ph.D. M.R.C.P. 2nd Edition. Pp. xi +443 , with 5 I illustrations. Edinburgh: E. \& S. Living stone. 195I. 30s.

In this book of just over 400 pages, Professoo Cruickshank has covered almost every aspect of food and nutrition-historic, economic and scientifie -and there can be few books which contain so mucts information in such a small compass and in such â readable form.

The introductory chapter entitled 'The Evolus tion of Human Dietaries ' deals briefly with the in fluence of racial and tribal differences and of sociald conditions on feeding habits. Then follows $a^{?}$ chapter on the problem of world malnutrition and the unequal distribution of food. Three chapters? are devoted to the problem of nutrition in Greap Britain, from the beginning of the first world ward 